\title{
Ebola: a West African perspective
}

\author{
EE Etuk \\ Consultant Paediatrician, Queen Esther Specialist Hospital, Uyo, Nigeria and Contract Consultant Paediatrician, General Hospital, Ikot \\ Ekpene, Akwa Ibom State, Nigeria
}

KEYWORDS control, Ebola, epidemic, outbreak, West Africa

DECLARATION OF INTERESTS No conflict of interest declared

\author{
Correspondence to EE Etuk \\ Queen Esther Specialist Hospital \\ PO Box 1981 \\ Uyo \\ Nigeria.
}

e-mail drestheretuk67@yahoo.co.uk
In December 2013 in Gueckedou, Guinea, West Africa, a 2-year-old child died. His mother, sister and grandmother later became ill with similar symptoms and also died.' This was the beginning of an end to the lives of so many West Africans. Other people in the village who had contact with this family died and the chain of death spread to other villages, towns and the neighbouring countries of Liberia and Sierra Leone. ${ }^{2}$ Gueckedou, in south-east Guinea, is an area where bat meat is frequently hunted and eaten. ${ }^{3}$ Researchers from the Robert Koch Institute in Berlin believe that this child was the index case in the current Ebola outbreak that is ravaging parts of West Africa. ${ }^{4}$ They believe that the child contracted the virus while playing near infected bats.

As at 22 December 2014, a year after the first index case, the World Health Organization (WHO) reported a total of 19,374 suspected cases and 7533 deaths. ${ }^{5}$ A small outbreak of 20 cases occurred in Nigeria, eight in Mali, one in Senegal, four in the USA and one in Spain. Despite Ebola being a major public health issue in subSaharan Africa, ${ }^{6}$ no cases had ever been reported in West Africa and most West African healthcare workers had never seen a case; hence the delay in early identification of the disease. ${ }^{7}$

The symptomatology of the disease is like many other diseases, e.g. lassa fever, malaria, typhoid, cholera, which are prevalent in the sub-region, so health workers failed to take the usual precautionary measures to prevent spread, like the wearing of gloves, personal protective equipment and constant washing of hands with soap and water. Thus the disease had many months to spread from human to human before it was identified as Ebola.

As at 15 February 20I5, the WHO and respective governments have reported a total of 23,253 suspected cases and 9380 deaths, ${ }^{8}$ though the WHO believes the figures are an underestimate of the magnitude of the problem. The case fatality rate in the current epidemic is up to $71 \%$.

\section{WHAT IS EBOLA?}

Ebola virus disease, formerly known as Ebola haemorrhagic fever, is a severe and often fatal illness with a mortality rate of up to $90 \%$, which affects humans and non-human primates such as monkeys, gorillas and chimpanzees. ${ }^{9}$ The first outbreak occurred simultaneously in 1976 in a village near the Ebola River (from where the disease gets its name) in the Democratic Republic of Congo (DRC; formerly Zaire) and in a remote area in Sudan. The origin is unknown but the fruit bat was considered the likely host. There are five strains of the virus and the strain in the current outbreak in Guinea is Ebola Zaire, the most lethal of the five strains and the same strain that caused outbreaks in the DRC. The outbreak in the DRC was limited to several hundred cases while the Guinea outbreak is exceptionally large.

The disease is transmitted through direct contact with the body fluids of an infected person. These include saliva, mucus, blood, sweat, urine, vomit, faeces and breast milk. It can also be transmitted through direct contact with the body fluids of a dead infected person through the unsafe cultural burial practice of washing the body of the deceased. This is the practice in West Africa and has contributed significantly to the rapid spread of the current epidemic. Handling infected animals or eating infected bush meat like the fruit bat is another means of transmission. In West Africa, bush meat is eaten as a delicacy in the form of meat in pepper soup.

The incubation period is $2-21$ days ${ }^{10}$ and patients become contagious once they begin to show symptoms. 
The symptoms include sudden onset of fever, intense weakness and muscle pain, joint pains, headache and sore throat followed by gastrointestinal symptoms, vomiting and diarrhoea, impaired kidney and liver function and, in some cases, external and internal bleeding.

\section{THE WEST AFRICAN RESPONSE}

The three worst affected countries in this outbreak are Guinea, Liberia and Sierra Leone and each responded by notifying the WHO of the outbreaks. Guinea notified on 21 March 20I4, Liberia on 30 March and Sierra Leone on 25 May. The WHO had a special ministerial meeting with representatives of II African countries, Centers for Disease Control (CDC) and non-governmental organisations (NGOs), from 2-3 July 20I4." A strategy was set up for an accelerated response to the Ebola outbreak and a regional Ebola response centre was opened in Conakry, Guinea. The committee advised that the Ebola outbreak in West Africa was an extraordinary event, a public health risk to other states and that a coordinated international response was deemed essential to stop and reverse the international spread of Ebola. On 8 August 2014, the WHO declared the Ebola outbreak as a 'Public Health Issue of International Concern' and on 28 August published a road map for a coordinated international response to the outbreak. The key elements required to prevent transmission are contact tracing and follow up, social mobilisation and public awareness.

Although the Ebola Zaire strain which caused the outbreaks in the DRC with limited transmission is the same one causing the outbreak in Guinea, the Guinea outbreak has been unprecedented in scale due to certain challenges which encourage rapid spread in these countries. These are weak health systems with significant deficits in human, financial and material resources, resulting in compromised ability to mount an adequate Ebola outbreak control response.

The other challenge is inexperience in dealing with Ebola outbreaks and a misperception of the disease and how it is transmitted. High mobility of populations and cross border movement of infected people allows for rapid spread from country to country. Here in the sub-region, citizens do not require visas or travel permits to move from one country to another. A high level of poverty in the affected areas and absence of running water has led to limited access to soap and water which are essential for the control of the infection. Inadequate infection control practices in many facilities have led to a high incidence of infection among health workers. Despite these challenges the national authorities of these countries have been working with the WHO and international partners and stakeholders to implement established outbreak response measures for Ebola control. The disease continued to spread in the affected countries forcing them to close their borders leaving few crossing points. Other measures included placing badly affected areas under quarantine, closing schools and universities, restricting public gatherings, and educating the public on how Ebola is spread and how to stay free of the disease. Sierra Leone banned the eating of bush meat. Nigeria and other countries in the African Union sent volunteers to the three affected countries to help in the fight. ${ }^{12}$ The Economic Community of West African States set up a special solidarity fund to help the three worst affected countries fight Ebola. ${ }^{13}$

\section{EBOLA OUTBREAK IN NIGERIA AND NIGERIA'S RESPONSE}

On 20 July 2014, the first case of Ebola occurred in Lagos, Nigeria, from Liberia. The patient was a LiberianAmerican whose sister had died of Ebola in Liberia. ${ }^{14}$ This index case was confirmed as Ebola on 23 July 2014 and the patient died on 25 July. Before he died he had spread the disease to health workers and a fellow patient in the hospital. All other cases of Ebola in Nigeria were linked to this man.

The reaction of Nigerians both within and outside the country to the arrival of Ebola in the country was close to panic, ${ }^{15}$ especially at a time when members of the Nigerian Medical Association were on strike. There was fear that the Nigerian health service would not be able to cope. A state of emergency was declared and the Nigerian Medical Association called off its strike to enable doctors to join in the fight against Ebola. Emergency operation centres, and isolation and treatment centres were established.

Suspected cases were isolated and managed. Very meticulous contact tracing was done and contacts were followed up for 21 days by officials. The Federal Government extended school closures, discouraged large gatherings and put in place preventive measures such as screening people at points of entry in and out of the country. Screening of people as they entered both government and private offices became a norm. Teachers were trained how to screen school children and others at point of entry to the school. Facilities for constant washing of hands with soap and water were provided in offices, schools and hospitals.

\section{The role of the media}

The media, both print and electronic, played a very important role in the fight against Ebola. Messages were disseminated urging people to avoid physical contact, to wash their hands frequently and avoid handshakes and hugs, which is the way of greeting people in our culture. There was a report of how a citizen used social media to misinform people that drinking and bathing with salt water was the cure for Ebola, and even though the 
misinformation was quickly countered by the Government it was not without casualties. People who did not want to die from Ebola ended up dying from drinking salt water. Eating of bush meat, a delicacy in Nigeria, was discouraged.

The role of private sector faith-based organisations and traditional institutions

All these organisations played their own part disseminating information to their subjects, providing screening tools, water, soap and hand sanitisers.

\section{The role of the masses}

Nigerians received the news of Ebola in the country with much fear. They were ready to carry out directives given by the Government to protect themselves from contracting the disease. The age long cultural way of greeting was changed to an 'Ebola greeting' which consisted of a bow similar to the Japanese greeting. ${ }^{16}$ The same style of greeting had also been reported by a Liberian during a symposium on Ebola at Rochester Brockports Department of African and African American Studies. Most people tried to maintain a very high level of personal and environmental hygiene. It was common to see people carrying hand sanitisers of all colours and hand sanitisers, soap and water were provided at homes, offices, churches, etc.

\section{WHO declares Nigeria Ebola free}

Meticulous contact tracing was carried out by Nigerian officials with the support of public health experts from the WHO, CDC and Médicins Sans Frontières. This helped to stop potential chains of transmission. One hundred percent of contacts in Lagos and $98 \%$ in Port Harcourt were followed up. In the end a total of 20 clinical cases and eight deaths were reported in Nigeria. Forty-two days after the last confirmed case, no new cases were reported in Nigeria and the WHO declared the country Ebola free on 20 October 2014. The WHO representative in Nigeria stated that it was a 'spectacular success story' and declared the feat 'a piece of world class epidemiological detective work'. ${ }^{17}$

\section{WESTERN RESPONSE TO THE OUTBREAK}

The President of Médicins Sans Frontières has criticised the response to the epidemic by the Western world and said that it has been too slow and the efforts to control it have been too scattered. Despite the growing international response and US contributions, the needs of the affected countries are still great. Healthcare workers and basic supplies are still lacking, making control difficult. The efforts of the foreign NGOs, international partners and countries that have assisted in one way or another and the healthcare workers who have lost their lives in the fight to control Ebola is very much appreciated but the problem is enormous and overwhelming. The Time Magazine naming of Ebola health workers as 'Time Magazine Person of the Year' is commendable.

\section{EFFECT OF EBOLA OUTBREAK ON THE AFFECTED COUNTRIES}

\section{Economy}

The economies of the three worst affected countries are on the brink of collapse. West African trade continues to acutely feel the pressure of the Ebola outbreak and export trade is estimated to be down by as much as $30 \%$ according to UK's shipping consultant Drewry. ${ }^{18}$ Growth in Sierra Leone fell to $4.0 \%$ from the $11.3 \%$ projected before the outbreak.

\section{Agricultural sector}

Due to restrictions on movement and loss of workforce through deaths, people are no longer going to markets as they should. Food processing chains are affected and up to a million people in the affected countries face starvation as their access to food is seriously hindered. ${ }^{19}$

\section{Education}

The continued closure of schools has a negative impact on education and the loss of workforce through deaths impacts negatively on the sector. ${ }^{20}$

\section{Effect on the health sector}

Statistics show that about $10 \%$ of the victims in this outbreak are healthcare workers. In countries like Liberia, Guinea and Sierra Leone with a limited number of health workers for the population, Ebola has a serious impact on the health sector.

\section{Effect on tourism}

Tourism in the affected countries has been adversely affected. Citizens of those countries faced a degree of stigmatisation outside their countries. Tourism in other countries in the region has also been adversely affected. Gambia's tourism has fallen below $50 \%$.

\section{TREATMENT OF EBOLA}

Currently, treatment is only supportive and includes fluid replacement either orally or intravenously. No specific drugs or vaccines are available for treatment and prevention, respectively, as vaccine developments are still at the experimental stage. Two potential vaccines are undergoing human safety trials.

\section{RECOMMENDATIONS}

All countries in the sub-region have to be in a state of emergency preparedness at all times as Ebola, or any other emerging disease, could develop at any time. 
EE Etuk

Emergency operation centres, isolation and treatment centres should be established. Healthcare systems should be strengthened, health infrastructure, including laboratories, should be improved and built and the capacity of health workers increased.

\section{REFERENCES}

I Ebola virus Epidemic in West Africa. Wikipedia. http://en.wikipedia org/wiki/Ebola_virus_epidemic_in_West-Africa (accessed 29/I/20I5).

2 Ebola: who is patient zero? Disease traced back to 2-year-old in Guinea. CNN 2I January 2015. http://www.cnn.com/20I4/I0/28/ health/ebola-patient-zero (accessed 23/2/20I5).

3 Ebola: Is bush meat behind the outbreak? BBC News 19 October 2014. http://www.bbc.co.uk/news/health-29604204 (accessed 29/1/2015)

4 Ebola virus epidemic in Guinea. Wikipedia. http://en.m.wikipedia. org/wiki/Ebola_virus_epidemic_in_Guinea (accessed 23/2/20I5).

5 Ebola data and statistics. Situation summary. Data published 22 December 20I4. World Health Organization. http://apps.who.int/ gho/data/view.ebola-sitrep.ebola-summary-20I4I 222?lang=en (accessed 29/I/20I5).

6 Baize S, Pannetier D, Oestereich L et al. Emergence of Zaire Ebola virus disease in Guinea. N Engl J Med 2014; 37I: |4|8-25. http:// dx.doi.org/I0.1056/NEJMoal404505

7 Ebola outbreak of 2014. Encyclopaedia Britannica. Last updated 16/2/20I5. http://www.britannica.com/EBchecked/topic//99|130/ Ebola-outbreak-of-20I4 (accessed 23/2/20I5).

8 Ebola data and statistics. Situation Summary. Data published 15 February 2015. World Health Organization. http://apps.who.int/ gho/data/view.ebola-sitrep.ebola-summary-latest?lang=en (accessed 23/2/2015).

9 Frequently asked questions on Ebola virus disease. World Health Organization. http://www.who.int/csr/disease/ebola/faq-ebola/en/ (accessed 29/1/20I5).

10 Ebola Virus disease.WHO Fact sheet No 103. Updated September 20I4. World Health Organization. http://www.who.int/ mediacentre/factsheets/fs I03/en/ (accessed 23/2/20I5).

I I Special Ministerial Meeting on Ebola Virus Disease in West Africa, Accra, Ghana, 2-3 July 2014. http://www.afro.who.int/en/clustersa-programmes/dpc/epidemic-a-pandemic-alert-and-response/eprhighlights/4 I87-special-ministerial-meeting-ebola-accra-2-3july-20I4.html (accessed 23/2/20I5).
Public utilities, which include the provision of running water, should be made generally available and fully functioning to enable citizens to continue to maintain a high level of personal hygiene. African countries should be involved in the management of the outbreak to acquire experience in case of future events.

12 Nigerian Ebola volunteers fly into Liberia, Sierra Leone. Reuters 5 December 20l4. http://www.reuters.com/article/20l4/I2/05/ us-health-ebola-idUSKCNOJJ0ZX20I4I 205 (accessed 29/I/20I5).

13 Ecowas establishes Ebola solidarity fund. Voice of Nigeria 12 July 20l4. http://www.voiceofnigeria.org/test/africa/ecowas-establishesebola-solidarity-fund.html

I4 Ebola in Nigeria Index case. Wikipedia. http://en.wikipedia.org/ wiki/Patrick_Sawyer (accessed 23/2/20I5).

I5 Nigeria's hard earned lesson for quashing Ebola. Financial Times 13 October 2014. http://www.ft.com/cms/s/2/4769ca32-52c4-I le4-a236-00 I44feab7de html\#axzz3SZOFWZTQ (accessed 23/2/20I5).

16 Symposium offers West African perspective on Ebola. Democrat \& Chronicle 8 November 2014. http://www.democratandchronicle. $\mathrm{com} / \mathrm{story} / \mathrm{news} / 20 \mathrm{I}$ 4/I I/08/ebola-symposium-WestAfrica/I8743959/ (accessed 23/2/20I5).

17 Nigeria is now free of Ebola Virus transmission. World Health Organization. http://www.who.int/mediacentre/news/ebola/20october-20I4/en/ (accessed 23/2/20I5).

18 Ebola:West Africa shipping down by $30 \%$. The Punch 27 November 2014. http://www.punchng.com/business/maritime/ebola-westafrican-shipping-down-by-30/ (accessed 29/I/20I5).

19 UN says Ebola-hit nations at risk of hunger. The Punch 18 December 20l4. http://www.punchng.com/news/un-says-ebolahit-nations-at-risk-of-hunger-2/ (accessed 29/I/20I5).

20 Ebola outbreak: Nigerians react as schools kept shut. BBC News 27 August 2014. http://www.bbc.co.uk/news/world-africa-28954406 (accessed 29/1/2015). 